Article

\title{
Geochemical Implications of Rare Earth Elements in Terra Rossa in Tropical Karst Area: A Case Study in Northern Vietnam
}

\author{
Zhang Liankai ${ }^{1,2}$, Ji Hongbing ${ }^{3, *(\mathbb{D}}$, Wang Shijie ${ }^{2}$, Luo Gang ${ }^{4}$, Liu Xiuming ${ }^{2}$, Wei Xiao ${ }^{2,5}$, \\ Nguyen QuocDinh ${ }^{6}$ and Nguyen DaiTrung ${ }^{6}$ \\ 1 Key Laboratory of Karst Ecosystem and Treatment of Rocky Desertification, Institute of Karst Geology, \\ Ministry of Natural Resources, Guilin 541004, China; zhangliankai@karst.ac.cn \\ 2 State Key Laboratory of Environmental Geochemistry, Institute of Geochemistry, Chinese Academy of \\ Sciences, Guiyang 550081, China; wangshijie@vip.skleg.cn (S.W.); liuxiuming@vip.gyig.ac.cn (X.L.); \\ weixiao@vip.gyig.ac.cn (X.W.) \\ 3 Civil \& Environment Engineering School, University of Science and Technology Beijing, \\ Beijing 100083, China \\ 4 Government of Duping Town, Zhenyuan County, Qiandongnan Miao and Dong Autonomous Prefecture, \\ Guizhou Province, Qiandongnan 522625, China; qnsdzlk@126.com \\ 5 College of Agriculture, Guizhou University, Guiyang 550025, China \\ 6 Vietnam Institute of Geosciences and Mineral Resources, Hanoi 100000, Vietnam; dinhnq@gmail.com (Q.N.); \\ trung_nd@yahoo.com (D.N.) \\ * Correspondence: ji.hongbing@hotmail.com; Tel.: +86-183-1131-2619
}

Received: 22 December 2019; Accepted: 22 January 2020; Published: 26 January 2020

check for updates

Featured Application: The data and methods in this article can be used for in-depth study of terra rossa in evolution process and paleoclimate reconstruction in the tropical karst regions, creating a new field for the study of laterite and paleoclimate in karst areas that lack modern eolian deposition.

\begin{abstract}
Research on weathered crusts on carbonate rock is essential for paleoenvironmental studies in karst areas. Terra rossa, widely distributed in tropical karst areas, has not been studied in terms of its material sources and geochemistry. Two typical terra rossa profiles on dolomite (SC profile located at Sang Cai, Hoa Binh province) and limestone (TG profile located at Tong Gia, Lao Cai province) in Northern Vietnam were selected to examine the geochemical characteristics and the evolutionary processes of rare earth elements (REEs). Chondrite and bedrock normalized patterns indicated that these two profiles are in situ weathering crusts, meaning they are the residual material remaining after chemical weathering of the lower carbonate rocks. The average value of total REE in the SC profile is $381.19 \mathrm{ppm}$, which is 30 times higher than the bedrock. In the TG profile, the value is $386.26 \mathrm{ppm}, 13$ times higher than the bedrock. Compared with the profiles in nearby subtropical areas in Southeast China, the REE enrichment coefficients of terra rossa in Northern Vietnam are much higher. The REE depletion was also different between the SC and TG profiles. The light and heavy REE fractionations in the SC profile are higher than in the TG profile. Paleoclimate inversion analysis shows that the SC profile experienced a stable oxidation condition, whereas the TG profile was subjected to several reducing environments since a weathering crust formed.
\end{abstract}

Keywords: carbonate rocks; terra rossa; rare earth elements; geochemistry 


\section{Introduction}

Terra rossa (lateritic weathering crusts) surfaces on carbonate rocks occupy an important position in karst environmental systems research [1]. These weathering crusts are regarded as an area of geochemical sensitivity and ecological vulnerability [2]. Carbonate rocks, covering approximately 15\% $\left(22\right.$ million $\mathrm{km}^{2}$ ) of the world's total land area, are mainly distributed in tropical and subtropical areas, such as Southeast Asia, the Mediterranean coast, and the Southeastern region of North America [3,4]. Southeast Asia is the largest contiguous karst area on Earth [5,6]. Showing strong effects of geochemistry and pedogenesis, the karst geology, geomorphology, and lateritic weathering crusts were formed as unique geological bodies compared with non-karst regions [7].

After multi-stage development, terra rossa recorded information about paleoenvironment and paleoclimatic changes [8,9]. This information is vital for paleoclimate analysis, especially in the karst regions that lack Cenozoic sediments $[10,11]$. In Southeast Asia, extensive amounts of lateritic weathering crusts overlaying carbonate rocks formed an intact area of terra rossa distribution within the tropical-subtropical monsoon climatic zones. The regions thus became ideal for the formation and evolution of research on lateritic and carbonate rock weathering. Some studies focused mostly on subtropical [12-14] and Mediterranean regions [15-17]; few focused on the tropical karst areas. Although Muhs and Budahn [18] researched the sources of laterite in the tropical West Indies region, they did not conduct in-depth investigations on the lateritic geochemical evolutionary processes.

Rare earth elements (REEs) serve as tracers and indicators of sources, weathering, diagenesis, and mineralization processes in the terrestrial critical zone [19]. Their contents, total amount, and combinational patterns objectively reflect the geological body's evolutionary process, the physical and chemical conditions, as well as the source $[20,21]$. As such, studies of the geochemical behavior of REEs in terra rossa can contribute to reconstructing the pedogenesis effects, weathering processes, and the supergene mineralization [22-24].

In this study, we selected two typical terra rossa profiles, covering dolomite and limestone, to investigate the evolutionary process of REEs in the tropical carbonate lateritic crusts to reveal their implications for environmental changes, geochemical characteristics, and elemental migration.

\section{Materials and Methods}

\subsection{Study Area Description}

Northern Vietnam is located at the intersection of two tectonic zones, the Tethys oceanic trench and Pacific Rim, and has undergone considerable uplifting and erosion [25]. The chronostratigraphic stratum here is mainly comprised of Paleozoic marine sediment that formed shale and limestone. The Indochina orogenic cycle occurred 150 million years ago, during when the geosyncline uplifted gradually. This process pushed the carbonate layer upward, which formed the karst mountains $1000-2800 \mathrm{~m}$ tall.

The SC profile is located at Sang Cai, Hoa Binh province, Northern Vietnam $\left(20^{\circ} 46^{\prime} 11.35^{\prime \prime} \mathrm{N}\right.$, $104^{\circ} 52^{\prime} 29.26^{\prime \prime}$ E) (Figure 1), at an altitude of $1135 \mathrm{~m}$. The $400-700 \mathrm{~m}$ thick bedrock is gray and grayish-white dolomite under the Upper Dong Giao Formation $\left(\mathrm{T}_{2} \mathrm{dg}_{1}\right)$. The overlay on the bedrock is yellowish-brown soil (Table 1), in which the rock-soil interface (RSI) is a grey-white powder layer 1-3 mm thick. $\mathrm{T}_{2} \mathrm{dg}_{1}$ formation is the main karst stratum in Northern Vietnam. It is exposed at $30^{\circ}-90^{\circ}$ and has well-developed fractures. The formations are 5-40 km wide and $400 \mathrm{~km}$ long, stretching from the Sino-Vietnamese border northwest of the coastal area in the east [26]. Generally, the climate is tropical monsoon, with an annual average temperature of $24^{\circ} \mathrm{C}$, which is lower than at the same latitude in Asia. The average annual rainfall is $1500-2000 \mathrm{~mm}$. The summer season is usually rainy and hot, affected by the southeast monsoon. 


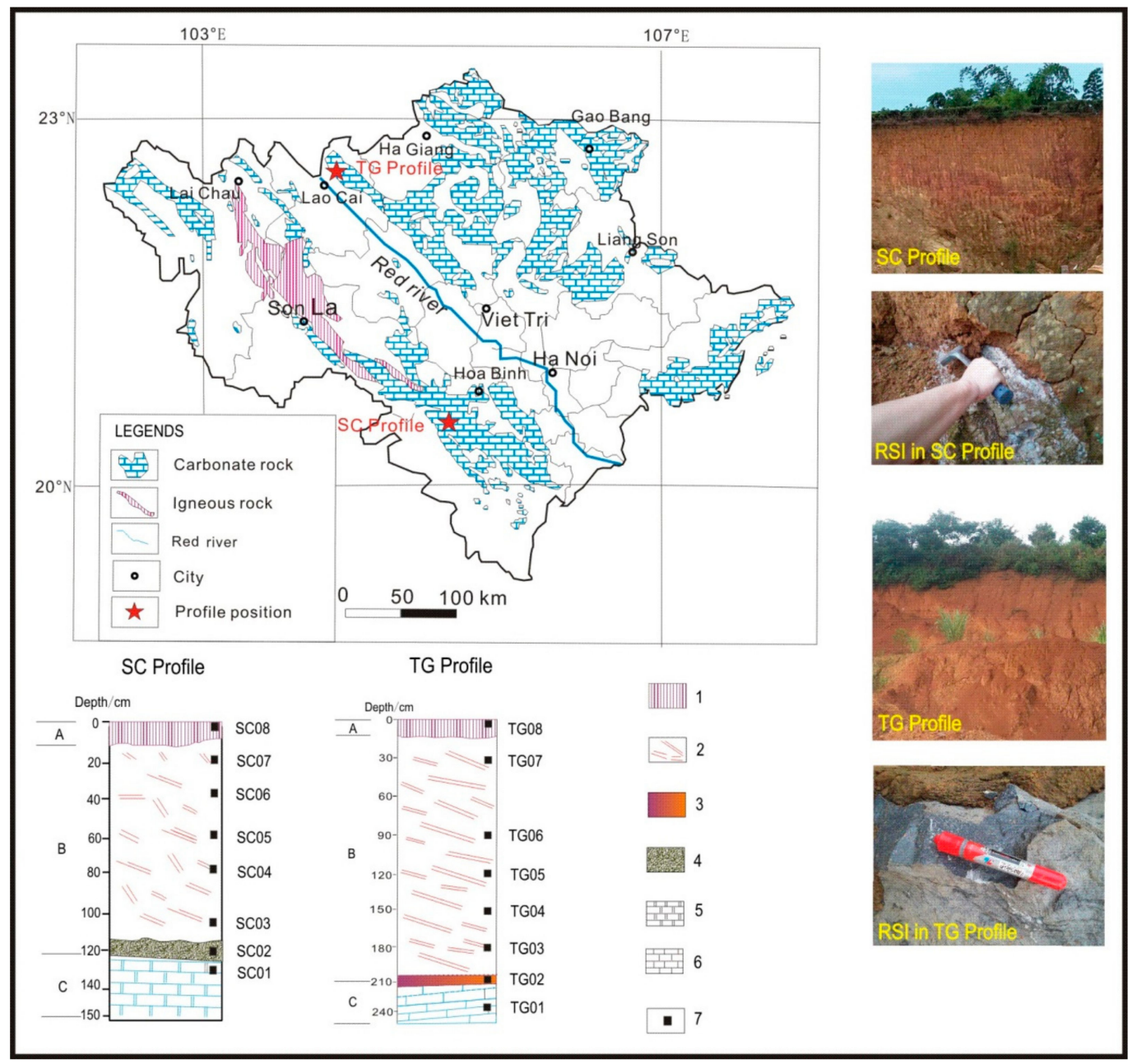

Figure 1. The simplified stratigraphic sketch of the SC dolomite and TG limestone (located at Sang Cai, Hoa Binh province and located at Tong Gia, Lao Cai province, respectively, showing the location of the numbered sampling points. 1, plow layer; 2 , terra rossa; 3, rock-soil interface (RSI) of dolomite rock (blackish-brown chocolate layer); 4, RSI of limestone (grey-white powder layer); 5, dolomite; 6 , limestone; 7, sampling point.

Table 1. Detailed information and sampling sites of the two typical laterite profiles*.

\begin{tabular}{clccccc}
\hline Layer & SC Profile & H $\mathbf{( c m})$ & No. & TG Profile & H (cm) & No. \\
\hline \multirow{3}{*}{ A } & Blackish-brown topsoil layer & 0 & SC08 & Dark-gray topsoil layer & 0 & TG08 \\
\cline { 2 - 7 } & Yellowish-brown soil layer & -20 & SC07 & Yellow soil layer & -30 & TG07 \\
\cline { 2 - 7 } & Yellowish-brown soil layer & -40 & SC06 & Yellowish-brown soil layer & -90 & TG06 \\
\hline \multirow{3}{*}{ B } & Yellowish-brown soil layer & -60 & SC05 & Yellowish-brown soil layer & -120 & TG05 \\
\cline { 2 - 7 } & Yellowish-brown soil layer & -80 & SC04 & Yellowish-brown soil layer & -150 & TG04 \\
\cline { 2 - 7 } & Yellowish-brown soil layer & -100 & SC03 & Yellowish-brown soil layer & -180 & TG03 \\
\cline { 2 - 7 } & Grey-white powder layer & -120 & SC02 & Blackish-brown layer & -210 & TG02 \\
\hline \multirow{2}{*}{ C } & Dolomite & -130 & SC01 & Limestone & -240 & TG01 \\
\hline
\end{tabular}

* A, B, and C are the soil genetic layers, corresponding to the topsoil, eluvial horizon, and bedrock, respectively; $\mathrm{H}$, the depth of profile and its sampling points; SC and TG profiles are the dolomite and limestone weathered profiles in Northern Vietnam. 
The TG profile is located at Tong Gia, Lao Cai province $\left(22^{\circ} 29^{\prime} 1.01^{\prime \prime} \mathrm{N}, 104^{\circ} 06^{\prime} 57.10^{\prime \prime} \mathrm{E}\right)$ (Figure 1); at an altitude of $128 \mathrm{~m}$. The bedrock of Ha Giang Formation $\left(\epsilon_{2} \mathrm{hg}_{2}\right)$ is comprised of marble, mottled limestone, clayish limestone, and clay-sericite schist, with a thick up to $1000 \mathrm{~m}$. Red river valley stretches northwest-southeast and is known for its hot and dry features. A blackish-brown layer is found at the RSI of the TG profile.

The sampling profiles were selected from the top of a hillock sited and manually excavated next to a highway. The weathering soil layer was about $100-300 \mathrm{~cm}$. Detailed information and sampling sites of the two terra rossa profiles are shown in Table 1.

\subsection{Samples Collection and Analytical Methods}

Samples were all collected from the top of karst mountains to avoid slope deposits. The profile samples were acquired in the upward direction from the bottom to the surface, ensuring that control samples were available for each type of weathered layer including the topsoil, lateritic, and bedrock layers. Both profiles were fresh, and the structure of the weathered layers was clear. We collected $500 \mathrm{~g}$ soil for each point with 20-30 cm intervals between each point (Table 1). All samples were sealed within polyethylene bags before transport to the laboratories. Then, they were air-dried and finely grinded in agate mortar into 200-mesh before analysis and dissolution [27].

The concentrations of REEs and major and trace elements were determined using acid digestion methods following the analytical procedures described by Ji et al. [28]. The chemical compounds REEs and major elements were analyzed at the China Nuclear Research Institute (CNNC) using a plasma mass spectrometer (ELEMENT XR, Thermo Scientific, Waltham, MA, USA) and fluorescence spectrophotometer (Axiosm A X, PANalytical, Almelo, Overijssel, Netherlands), respectively. The test temperature was $22.9{ }^{\circ} \mathrm{C}$, instrument precision was $<5 \%$ for trace elements and $2 \%$ for major elements, and the relative error between the sample results and recommended standard was $<10 \%$. The $\mathrm{pH}$ was measured as follows: $10 \mathrm{~g}$ of air-dried soil sample was passed through $1 \mathrm{~mm}$ sieve and added to a $100 \mathrm{~mL}$ beaker, we added $25 \mathrm{~mL}$ of fresh deionized water, which was then stirred thoroughly and allowed to stay for $30 \mathrm{~min}$. We measured the $\mathrm{pH}$ of the suspension with a calibrated $\mathrm{pH}$ meter (ST5000, Ohaus, NJ, USA). Soil total carbon (TC) and soil organic carbon (TOC) were determined using a TOC/TN analyzer (Multi N/C3100, Jena, Jena, Thuringia, Germany) in the karst environmental testing center, Ministry of Natural Resources, China, with an analysis error was less than $0.1 \%$.

\section{Results}

\subsection{Concentration of REEs}

The REE data and relevant parameters of the two profiles are listed in Table 2. The total REE ( $\Sigma$ REE) in the SC profile ranged from 313.47 to $608.95 \mathrm{ppm}$ and the average value was $381.19 \mathrm{ppm}$. The $\Sigma$ REE of SC bedrock was $12.65 \mathrm{ppm}$. The REE concentration was 30 times higher than in the bedrock. For the TG profile, $\Sigma$ REE ranged from 281.15 to $776.56 \mathrm{ppm}$ (average $386.26 \mathrm{ppm}$ ), which is closer to that of SC profile. The $\Sigma$ REE of limestone in the TG profile was $29.237 \mathrm{ppm}$, which is significantly higher than in the dolomite stone in SC. 
Table 2. The rare earth element (REE) concentration (ppm) and the parameters in bulk samples from the SC and TG profiles *

\begin{tabular}{|c|c|c|c|c|c|c|c|c|c|c|c|c|c|c|c|c|}
\hline \multirow{2}{*}{$\begin{array}{c}\text { Profile } \\
\text { No. }\end{array}$} & \multicolumn{8}{|c|}{ SC } & \multicolumn{8}{|c|}{ TG } \\
\hline & SC08 & SC07 & SC06 & SC05 & $\mathrm{SC} 04$ & $\mathrm{SC} 03$ & $\mathrm{SC} 02$ & SC01 & TG08 & TG07 & TG06 & TG05 & TG04 & TG03 & TG02 & TG01 \\
\hline Depth(cm) & 0 & -20 & -40 & -60 & -80 & -100 & -120 & -130 & 0 & -30 & -90 & -120 & -150 & -180 & -210 & -240 \\
\hline $\mathrm{La}$ & 57.0 & 52.7 & 48.1 & 51.3 & 58.6 & 65.3 & 103 & 2.08 & 57.4 & 56.4 & 69.5 & 56.8 & 67.0 & 51.8 & 133 & 8.11 \\
\hline $\mathrm{Ce}$ & 133 & 127 & 122 & 120 & 132 & 147 & 157 & 3.94 & 141 & 96.4 & 94.2 & 113 & 106 & 85.9 & 80.8 & 7.74 \\
\hline $\operatorname{Pr}$ & 12.7 & 11.6 & 11.0 & 11.6 & 13.1 & 14.1 & 25.0 & 0.48 & 12.1 & 12.0 & 14.9 & 12.1 & 14.7 & 11.4 & 34.3 & 1.25 \\
\hline $\mathrm{Nd}$ & 50.9 & 45.9 & 44.4 & 46.0 & 52.0 & 55.8 & 103 & 1.92 & 47.0 & 46.5 & 58.6 & 47.6 & 57.2 & 43.5 & 134 & 4.58 \\
\hline $\mathrm{Sm}$ & 10.4 & 9.03 & 9.20 & 9.12 & 10.0 & 10.8 & 21.7 & 0.38 & 8.96 & 8.81 & 11.4 & 9.54 & 11.3 & 8.65 & 30.0 & 0.80 \\
\hline $\mathrm{Eu}$ & 2.25 & 1.95 & 1.98 & 1.87 & 2.16 & 2.25 & 4.44 & 0.08 & 1.73 & 1.71 & 2.19 & 1.94 & 2.14 & 1.68 & 6.68 & 0.15 \\
\hline $\mathrm{Gd}$ & 9.37 & 8.12 & 7.99 & 8.62 & 10.0 & 9.52 & 19.7 & 0.40 & 8.56 & 8.36 & 9.98 & 8.60 & 10.2 & 8.10 & 32.0 & 0.66 \\
\hline Dy & 9.91 & 8.84 & 8.47 & 8.87 & 9.64 & 10.2 & 21.8 & 0.38 & 7.69 & 8.06 & 9.69 & 8.92 & 9.71 & 8.18 & 37.2 & 0.68 \\
\hline Ho & 2.05 & 1.77 & 1.83 & 1.78 & 1.93 & 2.05 & 4.09 & 0.09 & 1.54 & 1.53 & 1.87 & 1.75 & 1.96 & 1.62 & 7.56 & 0.12 \\
\hline $\mathrm{Er}$ & 6.26 & 5.35 & 5.15 & 5.09 & 5.81 & 5.67 & 12.0 & 0.23 & 4.70 & 4.64 & 5.51 & 4.66 & 5.34 & 4.75 & 20.4 & 0.31 \\
\hline $\mathrm{Tm}$ & 1.07 & 0.97 & 0.96 & 0.92 & 1.01 & 1.11 & 1.92 & 0.05 & 0.73 & 0.84 & 0.88 & 0.91 & 0.98 & 0.77 & 3.34 & 0.05 \\
\hline $\mathrm{Yb}$ & 6.50 & 5.35 & 5.46 & 5.12 & 5.98 & 6.15 & 11.2 & 0.36 & 4.35 & 4.38 & 5.29 & 4.65 & 5.13 & 4.20 & 16.6 & 0.34 \\
\hline $\mathrm{Lu}$ & 1.18 & 0.97 & 1.09 & 1.00 & 1.06 & 1.03 & 2.14 & 0.05 & 0.76 & 0.80 & 0.88 & 0.79 & 0.91 & 0.72 & 2.92 & 0.07 \\
\hline Y & 51.8 & 45.7 & 44.3 & 45.6 & 52.8 & 53.8 & 118 & 2.15 & 43.0 & 43.9 & 52.8 & 49.7 & 52.7 & 48.4 & 231 & 4.26 \\
\hline$\Sigma$ REE & 356 & 327 & 313 & 318 & 358 & 387 & 609 & 12.7 & 341 & 296 & 339 & 323 & 347 & 281 & 777 & 29.2 \\
\hline$\Sigma$ LREE & 266 & 248 & 237 & 240 & 268 & 295 & 414 & 8.88 & 268 & 222 & 251 & 241 & 258 & 203 & 419 & 22.6 \\
\hline$\Sigma$ HREE & 90.0 & 78.7 & 76.8 & 78.6 & 90.0 & 91.3 & 195 & 3.77 & 72.8 & 74.0 & 88.7 & 81.7 & 88.8 & 78.2 & 358 & 6.61 \\
\hline$\Sigma$ LREE/ $/ \Sigma$ HREE & 2.96 & 3.15 & 3.08 & 3.05 & 2.98 & 3.24 & 2.13 & 2.35 & 3.68 & 3.00 & 2.83 & 2.95 & 2.91 & 2.59 & 1.17 & 3.42 \\
\hline$(\mathrm{La} / \mathrm{Yb})_{\mathrm{N}}$ & 6.29 & 7.07 & 6.32 & 7.19 & 7.03 & 7.62 & 6.60 & 4.19 & 9.47 & 9.24 & 9.42 & 8.76 & 9.37 & 8.85 & 5.75 & 17.2 \\
\hline$(\mathrm{La} / \mathrm{Sm})_{\mathrm{N}}$ & 3.54 & 3.77 & 3.38 & 3.63 & 3.79 & 3.90 & 3.06 & 3.56 & 4.14 & 4.13 & 3.94 & 3.84 & 3.83 & 3.87 & 2.86 & 6.57 \\
\hline$(\mathrm{Gb} / \mathrm{Yb})_{\mathrm{N}}$ & 1.19 & 1.26 & 1.21 & 1.39 & 1.38 & 1.28 & 1.46 & 0.93 & 1.63 & 1.58 & 1.56 & 1.53 & 1.64 & 1.60 & 1.59 & 1.63 \\
\hline$\delta \mathrm{Ce}$ & 1.21 & 1.26 & 1.30 & 1.21 & 1.17 & 1.19 & 0.76 & 0.97 & 1.31 & 0.91 & 0.72 & 1.06 & 0.83 & 0.87 & 0.29 & 0.60 \\
\hline$\delta \mathrm{Eu}$ & 0.70 & 0.70 & 0.71 & 0.64 & 0.66 & 0.68 & 0.66 & 0.66 & 0.60 & 0.61 & 0.63 & 0.65 & 0.61 & 0.61 & 0.66 & 0.63 \\
\hline TC(\%) & 1.4 & 0.74 & 0.58 & 0.59 & 0.48 & 0.99 & 1.75 & - & 2.12 & 0.36 & 0.28 & 0.2 & 0.15 & 0.15 & 0.43 & - \\
\hline TOC(\%) & 1.31 & 0.49 & 0.43 & 0.51 & 0.36 & 0.59 & 1 & - & 2.1 & 0.31 & 0.23 & 0.14 & 0.1 & 0.1 & 0.42 & - \\
\hline TOC/TC & 0.94 & 0.66 & 0.74 & 0.86 & 0.75 & 0.6 & 0.57 & - & 0.99 & 0.86 & 0.82 & 0.7 & 0.67 & 0.67 & 0.98 & - \\
\hline
\end{tabular}

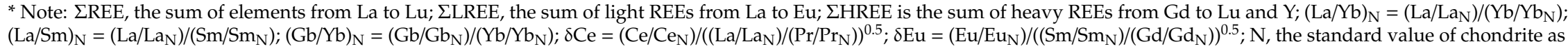

reported in the literature [29]; - , not detected. 
The $\Sigma$ REE in both SC and TG profiles showed fluctuating increases from top to bottom, as shown in Figure 2. For example, at the upper layer of SC profile (from 0 to $-100 \mathrm{~cm}$ ), the $\Sigma$ REE was $313.47-356.24 \mathrm{ppm}$, whereas at the weathering front $(-120 \mathrm{~cm})$, the value was $608.95 \mathrm{ppm}$. For the TG profile, the $\Sigma$ REE in the upper layer (from 0 to $-180 \mathrm{~cm}$ ) was $281.15-347.13 \mathrm{ppm}$, reaching $776.56 \mathrm{ppm}$ at RSI. This suggests that the REEs gradually leached away above the RSI and accumulated at the RSI.
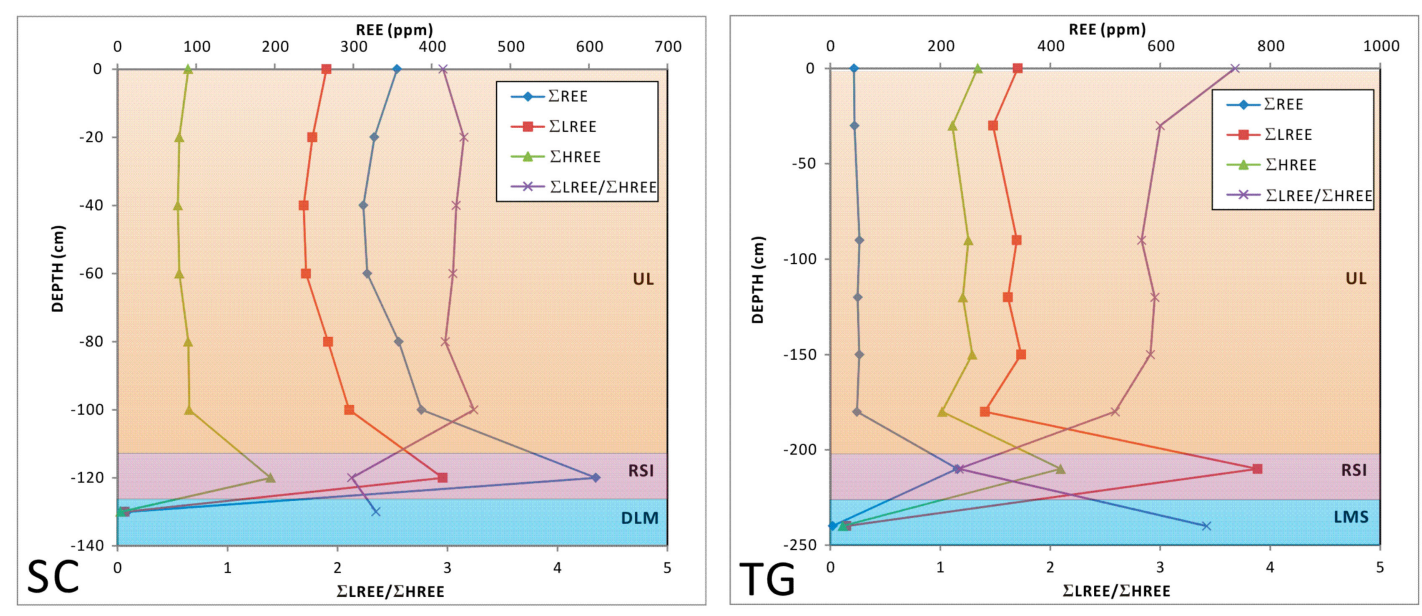

Figure 2. Variation curve of $\Sigma$ REE (the sum of REEs), $\Sigma$ LREE (the sum of light REE from La to Eu), $\Sigma$ HREE (the sum of heavy REE from Gd to Lu and Y), and the ratios of $\Sigma$ LREE/ $\Sigma$ HREE with depth in SC and TG profiles. UL, RSI, DLM, and LMS denote upper layer, rock-soil interface, dolomite, and limestone, respectively. LREE and HREE denote the light REE and heavy REE as illustrated in Table 2.

The $\Sigma$ LREE/ $\Sigma$ HREE ratio is the fractionation indicator for light REE (LREE, from La to Eu) and heavy REE (HREE, from Gd to Lu and Y). The fractionation of $\Sigma$ REE in the SC profile is slightly higher than in the TG profile. In the SC profile, the $\Sigma$ LREE/ $\Sigma$ HREE ratio ranges from 2.12 to 3.23 from topsoil to RSI (average: 2.94), showing a generally declining trend with the highest value at $-100 \mathrm{~cm}(3.24)$, and the lowest (2.12) at $-120 \mathrm{~cm}$ (RSI) (Figure 2). For the TG profile, the trend declined with the lowest value at the RSI $(-210 \mathrm{~cm}$ ) (Figure 2). This indicates that the leaching rate of LREE increased from top to bottom with the highest value at the RSI. The HREE gradually gathered from topsoil to bottom and peaked at the RSI. This result was confirmed at the subtropical weathering crusts covering on carbonate rocks by Nesbitt [30], Lan [31], and Sun et al. [32].

Geochemical parameters such as $\mathrm{Ce}$ and Eu of sedimentary rocks can be used to judge material source and sedimentary environment [21]. Normally, $\mathrm{Ce}>0.78$ is a positive anomaly, and $\mathrm{Ce}<0.78$ is a negative anomaly; $\mathrm{Eu}>1$ is a positive anomaly, and $\mathrm{Eu}<1$ is a negative anomaly [27].

Ce showed a positive anomaly at the top of the SC profile, with the $\delta$ Ce value ranging from 1.19 to 1.30 (average: 1.22). Its negative anomalies were lower at the weathering front of RSI, where the $\delta \mathrm{Ce}$ value was 0.76 . The TG profile shows that the highest positive anomaly $(\delta \mathrm{Ce}=1.31)$ was at the surface soil, with the lowest negative anomaly was at the RSI $(\delta \mathrm{Ce}=0.29)$. $\delta$ Eu was a relatively stable negative anomaly. The $\delta \mathrm{Eu}$ values for SC were 0.68 (ranging from 0.64 to 0.71 ) and 0.67 in the soil and bedrock, respectively. For the TG profile, $\delta \mathrm{Eu}$ was 0.63 , equal to the $\delta \mathrm{Eu}$ value for bedrock (Figure 3). 

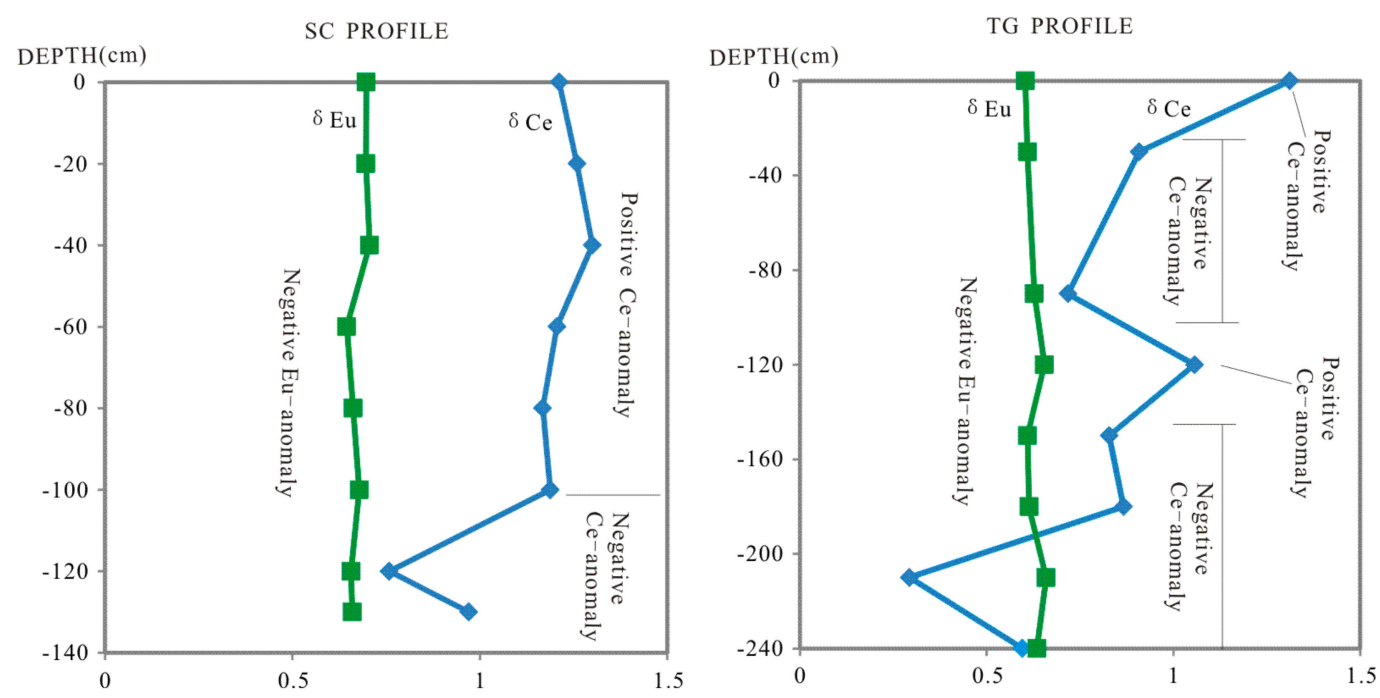

Figure 3. Variation curves of $\delta \mathrm{Ce}$ and $\delta \mathrm{Eu}$ with depth in SC and TG profiles. $\delta \mathrm{Ce}>1$ indicates a positive anomaly; $\delta \mathrm{Ce}<1$ indicates negative anomaly. The same applied to $\mathrm{Eu}$.

The specific elements ratios such as $(\mathrm{La} / \mathrm{Yb})_{\mathrm{N}},(\mathrm{La} / \mathrm{Sm})_{\mathrm{N}}$, and $(\mathrm{Gb} / \mathrm{Yb})_{\mathrm{N}}$, which can indicate the differentiation characteristics of LREE and HREE, are shown in Figure 4. The $(\mathrm{La} / \mathrm{Yb})_{\mathrm{N}}$ in SC profile is 4.10-8.47, with the average value of 6.87 (from 0 to $-120 \mathrm{~cm}$ ), which was lower than that of sandstone, granite, and gneiss (10.39, 7.65, and 8.17, respectively) as reported by Yang et al. [33]. The value gradually decreased along the rock layer $\rightarrow$ weathering layer $\rightarrow$ arable layer direction (Figure 4), with declining LREE from topsoil to RSI as indicated by $\Sigma$ LREE/ $\Sigma$ HREE. The averages of $(\mathrm{La} / \mathrm{Sm})_{\mathrm{N}}$ and $(\mathrm{Gb} / \mathrm{Yb})_{\mathrm{N}}$ were 3.58 and 1.31 , respectively.
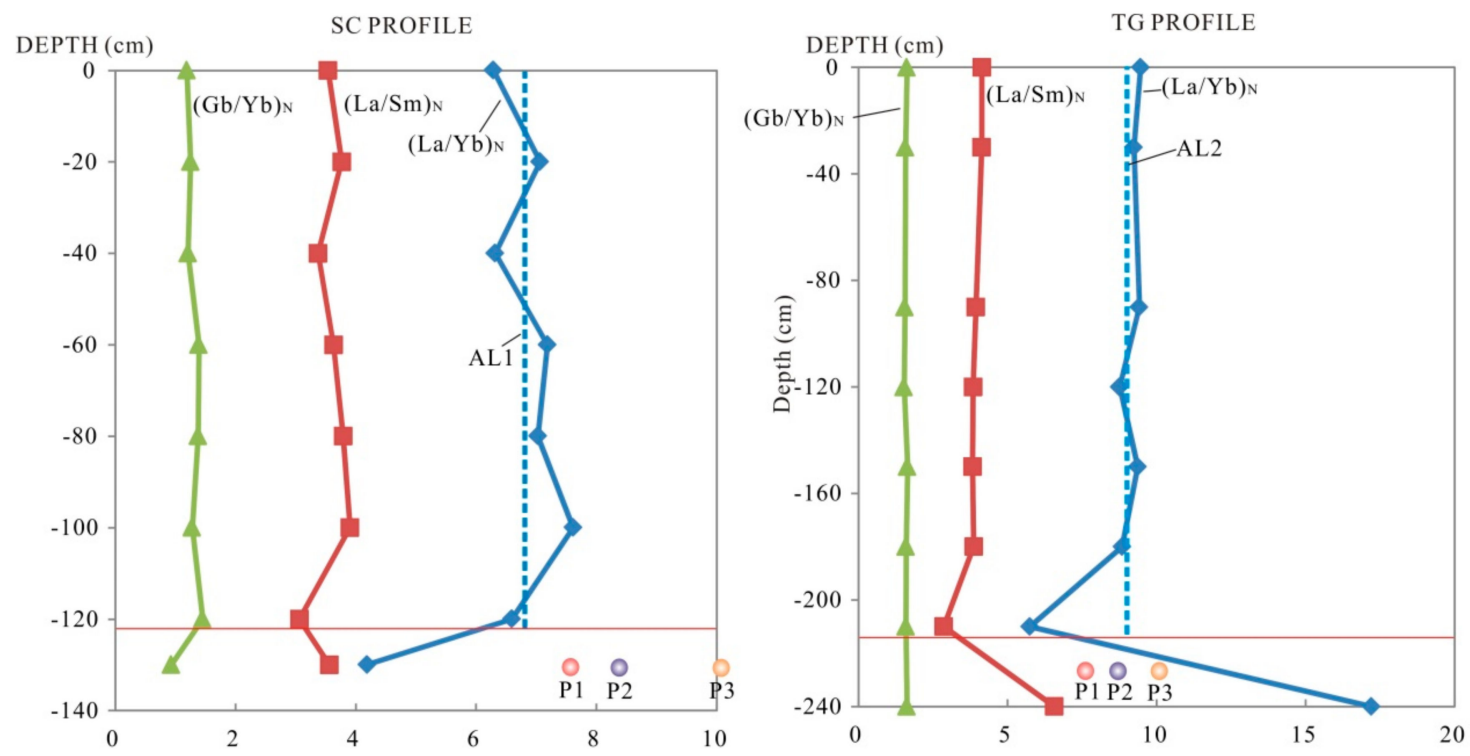

Figure 4. The variation of $(\mathrm{La} / \mathrm{Yb})_{\mathrm{N}},(\mathrm{La} / \mathrm{Sm})_{\mathrm{N}}$, and $(\mathrm{Gb} / \mathrm{Yb})_{\mathrm{N}}$ in $\mathrm{SC}$ and TG profiles. AL1, average line of $(\mathrm{La} / \mathrm{Yb})_{\mathrm{N}}$ from RSI to the top soil in SC profile; AL2, average line of $(\mathrm{La} / \mathrm{Yb})_{\mathrm{N}}$ from RSI to top soil in TG profile; $\mathrm{P} 1$, average point of $(\mathrm{La} / \mathrm{Yb})_{\mathrm{N}}$ in granite; $\mathrm{P} 2$, average point of $(\mathrm{La} / \mathrm{Yb})_{\mathrm{N}}$ in gneiss; $\mathrm{P}$, average point of $(\mathrm{La} / \mathrm{Yb})_{\mathrm{N}}$ in sandstone. The average data of $(\mathrm{La} / \mathrm{Yb})_{\mathrm{N}}$ in granite, gneiss, and sandstone were cited from Yang et al. [33].

In the TG profile, the $(\mathrm{La} / \mathrm{Yb})_{\mathrm{N}}$ varies along the rock $\rightarrow$ weathering layer $\rightarrow$ arable layer direction, reaching a maximum of 10.41 in the surface soil (Figure 4). A large differentiation occurred in the surface arable layer. $(\mathrm{La} / \mathrm{Yb})_{\mathrm{N}},(\mathrm{La} / \mathrm{Sm})_{\mathrm{N}}$, and $(\mathrm{Gb} / \mathrm{Yb})_{\mathrm{N}}$ in the TG profile were $8.69,3.80$, and 1.59, 
respectively. Those three ratios decreasing from surface to bottom indicate that LREE leached and HREE accumulated gradually from topsoil to the RSI.

\subsection{Comparison with Other Geological Bodies and Profiles}

Table 3 provides the REE content in different rocks, sediments, and soils on the Earth. Compared with these geological bodies and profiles, the REEs in bedrocks of dolomite and limestone in Northern Vietnam are one-half or one-third of that in weathering crust. The $\Sigma$ REE in Northern Vietnam profiles was basically the same as in the subtropical profiles. The enrichment factors (EFs) of REEs in Northern Vietnam profiles were 1.5 to 2.0 times those of the subtropical karst profiles. At the RSI of Vietnam profiles, the EFs were much higher, accounting to 2.5 to 3.3 times that of Chinese subtropical profiles. Compared with the loess, marine sediment, and fluvial lacustrine deposits around the world, the $\Sigma$ REE in SC and TG profile were two times higher than those geological bodies as shown in Table 3.

Table 3. Comparison of REE concentration (ppm) in different rocks, sediments, and soils on the Earth*.

\begin{tabular}{ccccccccccccccccc}
\hline Elements & La & Ce & Pr & Nd & Sm & Eu & Gd & Tb & Dy & Ho & Er & Tm & Yb & Lu & $\Sigma \mathbf{R E E}$ & References \\
\hline Loess & 32.3 & 67.4 & 7.00 & 28.8 & 5.70 & 12.7 & 4.60 & 0.80 & 4.40 & 0.90 & 2.60 & 0.40 & 2.60 & 0.40 & 194 & {$[22]$} \\
QS & 41.0 & 83.0 & 9.70 & 32.0 & 6.40 & 1.20 & 5.60 & 1.00 & 5.40 & 1.60 & 3.80 & 0.60 & 3.60 & 0.70 & 196 & {$[34]$} \\
UCC & 30.0 & 60.0 & 8.20 & 28.0 & 6.00 & 1.20 & 5.40 & 0.90 & 3.00 & 1.20 & 2.80 & 0.50 & 3.00 & 0.50 & 184 & {$[35]$} \\
LE & 16.4 & 30.8 & 3.70 & 17.8 & 2.90 & 0.60 & 2.90 & 0.40 & 2.50 & 0.40 & 1.00 & 0.20 & 1.30 & 0.20 & 92.0 & {$[36]$} \\
DSC & 6.90 & 5.40 & 3.40 & 4.60 & 2.00 & 1.20 & 1.90 & 0.90 & 1.30 & 0.60 & 0.80 & 0.50 & 0.70 & 0.40 & 31.0 & {$[14,27,32]$} \\
LSC & 11.3 & 15.5 & 4.80 & 7.10 & 2.50 & 0.90 & 1.70 & 0.80 & 1.30 & 0.60 & 0.80 & 0.40 & 0.70 & 0.40 & 49.0 & {$[14,27,32]$} \\
PDC & 101 & 172 & 34.0 & 138 & 36.0 & 7.00 & 25.0 & 5.00 & 21.0 & 4.00 & 10.0 & 2.00 & 11.0 & 2.00 & 566 & {$[14,27,32]$} \\
PLC & 83.0 & 121.6 & 22.0 & 87.1 & 19.2 & 4.10 & 18.2 & 2.70 & 15.7 & 2.90 & 7.80 & 1.10 & 6.60 & 0.90 & 393 & {$[14,27,32]$} \\
DNV & 2.08 & 3.94 & 0.48 & 1.92 & 0.38 & 0.08 & 0.4 & 0.07 & 0.38 & 0.09 & 0.23 & 0.05 & 0.36 & 0.05 & 12.7 & this research \\
LNV & 8.11 & 7.74 & 1.25 & 4.58 & 0.8 & 0.15 & 0.66 & 0.11 & 0.68 & 0.12 & 0.31 & 0.05 & 0.34 & 0.07 & 29.2 & this research \\
PDV & 62.3 & 134 & 14.2 & 56.9 & 11.5 & 2.41 & 10.5 & 2.01 & 11.1 & 2.21 & 6.48 & 1.13 & 6.53 & 1.21 & 381 & this research \\
PLV & 70.3 & 102 & 15.9 & 62.1 & 12.7 & 2.58 & 12.3 & 2.37 & 12.8 & 2.55 & 7.14 & 1.21 & 6.37 & 1.11 & 386 & this research \\
\hline
\end{tabular}

* UCC, upper continental crust [35]; QS, quaternary sediments; LE, lithosphere on the Earth; DSC, dolomite in China; LSC, limestone in China; PLC, profile on limestone in Southern China; PDC, profile on dolomite in Southern China; DNV, dolomite in Northern Vietnam; LNV, limestone in Northern Vietnam; PDV, profile on dolomite in Northern Vietnam; PLV, profile on limestone in Northern Vietnam.

\subsection{Normalized REE Distribution Patterns}

The $\mathrm{C} 1$ chondrite-normalized pattern, which smooths the elements distribution curve and enables comparison with the standard sample, is often used to eliminate the jaggedness of the REE odd-even effect that occurs during weathering process [30,31,37-40]. The C1 chondrite-normalized REE distribution patterns are shown in Figure 5. The curves of these two profiles exhibited the same models: both soil and bedrocks tilted to the right and relatively flat after Sm. This indicates that LREE are enriched in the profile, whereas HREE are relatively deficient. All REE distribution patterns showed relatively tendencies in bedrock, RSI, and surface soil. This trend reflected the inheritance of crusts materials from bedrock. Two profiles expressed the V-shaped troughs for Sm anomalies, indicating negative Sm anomalies in each layer of both SC and TG profile. Ce displayed a disordered appearance, generally, showing V-type negative anomalies and nearly positive anomalies at the RSI. All elements' $\mathrm{C} 1$ chondrite-normalized lines in profiles were higher than Vietnam bedrock chondrite-normalized lines (SC01 and TG01). Therefore, the tropical carbonate weathering crusts always have a high REE accumulative effect.

In the bedrock-normalized REE distribution pattern (Figure 6), the weathering crust showed significant REE enrichment. The $\Sigma$ REE was more than 10 times higher than in the bedrock. The curves showed the same tendency from RSI to topsoil. The SC showed a right-out characteristic, which means LREE enrichment and HREE loss. Ce presented a positive Ce anomaly valley in both SC and TG profiles. The REE in RSI showed extremely high and fluctuating changes. 

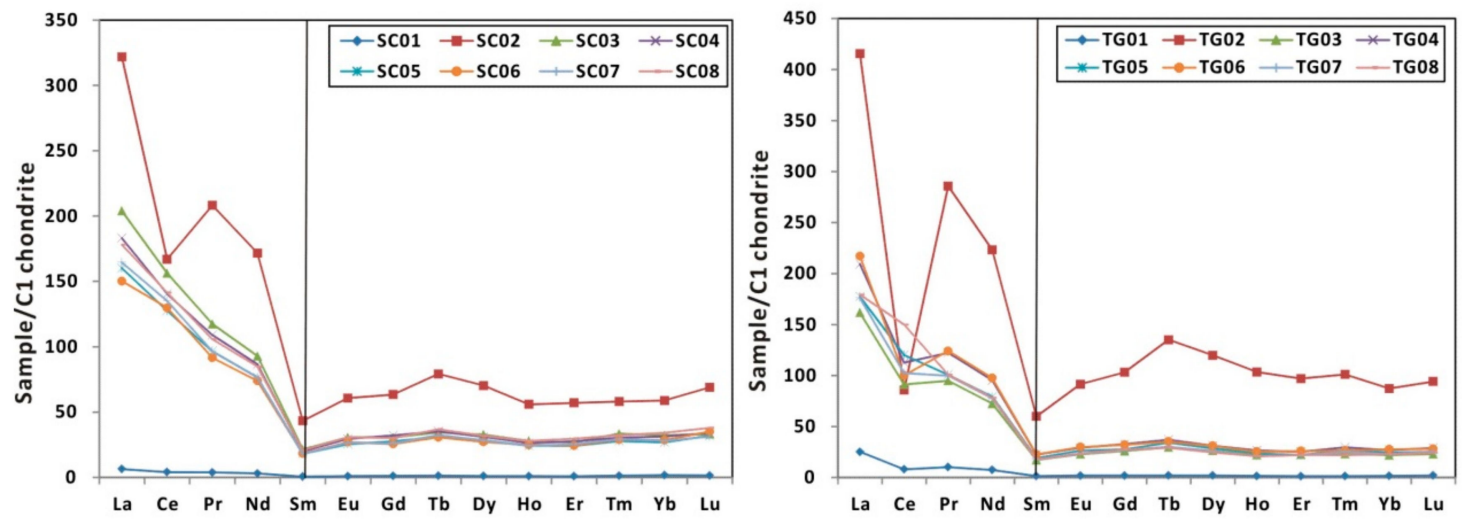

Figure 5. C1 Chondrite-normalized REE patterns of samples of the SC and TG profiles. The concentration was normalized to Chondrite after Taylor and Mclennan [22].
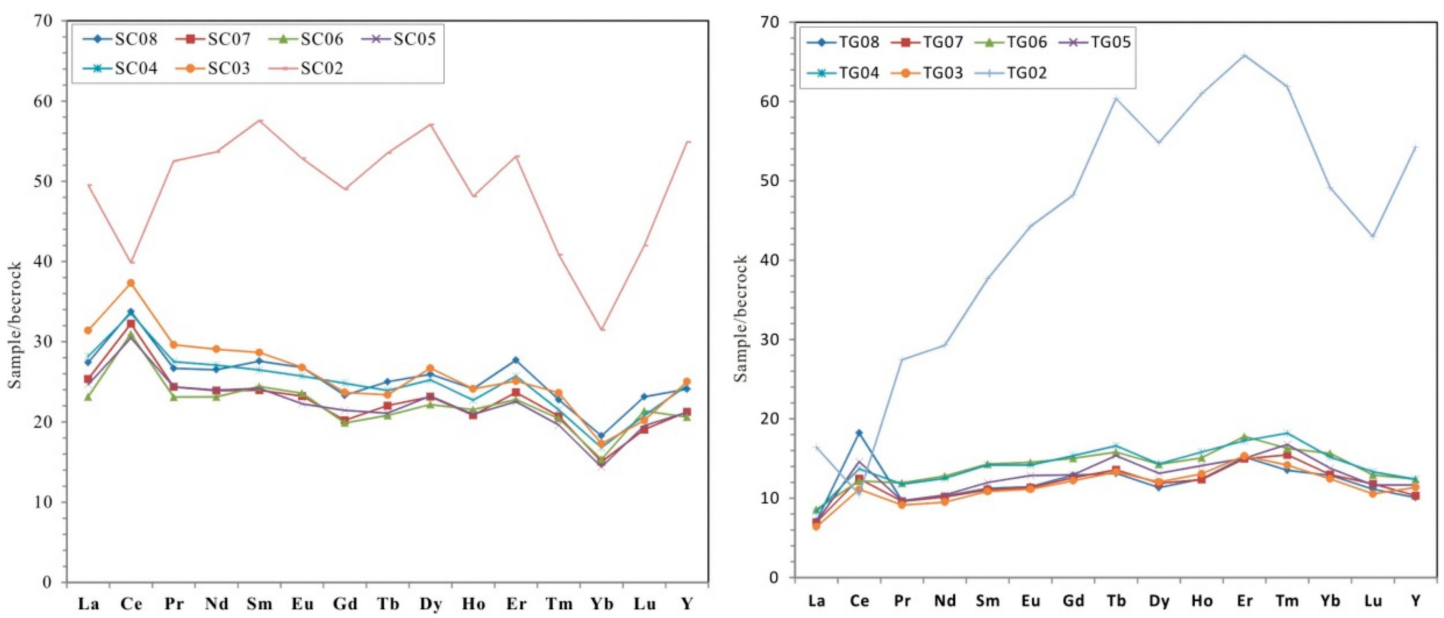

Figure 6. Bedrock-normalized REE distribution patterns for samples from the SC and the TG profiles.

\section{Discussion}

\subsection{Supergene Enrichment of REE}

\subsubsection{Enrichment of REE in Terra Rossa in Northern Vietnam}

REE supergene enrichment under the weathering process had been widely reported on laterite overlaying granite, basalt, and alkaline rocks [41-44]. Some studies focused on the carbonate rock weathering crusts in subtropical areas [32,45], but few had been conducted on tropical terra rossa [13,14,24,46].

To identify the main factors that affect the enrichment of REE in Northern Vietnam, we analyzed the correlation between REE and major elements. The results are shown in Table 4. REE, LREE, and HREE are extremely significantly and positively correlated with $\mathrm{Al}_{2} \mathrm{O}_{3}, \mathrm{Fe}_{2} \mathrm{O}_{3}, \mathrm{TiO}$, and $\mathrm{Zr}$, and especially with Fe. The correlation with $\mathrm{CaO}$ and $\mathrm{MgO}$ was negative, especially with $\mathrm{SiO}_{2}$. This indicates that the content of REE in the study area is controlled by $\mathrm{SiO}_{2}, \mathrm{Al}_{2} \mathrm{O}_{3}, \mathrm{Fe}_{2} \mathrm{O}_{3}, \mathrm{TiO}_{2}$, and $\mathrm{Zr}$, etc. The laterite profile of SC and TG profiles experienced the aluminum-rich and desilication stage, during which the Si was lost, and Fe and Al were enriched. At this stage, rare earth elements were co-deposited with $\mathrm{Al}$ and Fe. 
Table 4. Correlation analysis of REE and major elements.

\begin{tabular}{|c|c|c|c|c|c|c|c|c|c|c|c|c|c|c|c|}
\hline & REE & LREE & HREE & $\mathrm{SiO}_{2}$ & $\mathrm{Al}_{2} \mathrm{O}_{3}$ & $\mathrm{Fe}_{2} \mathrm{O}_{3}$ & $\mathrm{MgO}$ & $\mathrm{CaO}$ & $\mathrm{Na}_{2} \mathrm{O}$ & $\mathrm{K}_{2} \mathrm{O}$ & $\mathrm{MnO}$ & $\mathrm{TiO}_{2}$ & $\mathrm{P}_{2} \mathrm{O}_{5}$ & $\mathrm{FeO}$ & $\mathrm{Zr}$ \\
\hline REE & 1 & & & & & & & & & & & & & & \\
\hline LREE & $0.999 * *$ & 1 & & & & & & & & & & & & & \\
\hline HREE & $0.974 * *$ & $0.966^{* *}$ & 1 & & & & & & & & & & & & \\
\hline $\mathrm{SiO} 2$ & $-0.818^{* *}$ & $-0.814^{* *}$ & $-0.827^{* *}$ & 1 & & & & & & & & & & & \\
\hline $\mathrm{Al} 2 \mathrm{O} 3$ & $0.782 * *$ & $0.779 * *$ & $0.783 * *$ & $-0.947 * *$ & 1 & & & & & & & & & & \\
\hline $\mathrm{Fe} 2 \mathrm{O} 3$ & 0.810 ** & $0.797 * *$ & $0.874 * *$ & -0.886 ** & & 1 & & & & & & & & & \\
\hline $\mathrm{MgO}$ & -0.197 & -0.184 & -0.285 & 0.237 & -0.247 & -0.503 & 1 & & & & & & & & \\
\hline $\mathrm{CaO}$ & -0.033 & -0.011 & -0.186 & 0.182 & -0.225 & -0.342 & 0.108 & 1 & & & & & & & \\
\hline $\mathrm{Na} 2 \mathrm{O}$ & -0.326 & -0.317 & -0.377 & 0.411 & -0.456 & -0.279 & 0.040 & 0.604 & 1 & & & & & & \\
\hline $\mathrm{K} 2 \mathrm{O}$ & -0.530 & -0.518 & $-0.595^{*}$ & $0.759 * *$ & $-0.700 *$ & $-0.719 * *$ & 0.569 & 0.141 & 0.290 * & 1 & & & & & \\
\hline $\mathrm{MnO}$ & -0.541 & -0.527 & $-0.621 *$ & 0.566 & -0.487 & -0.647 * & 0.575 & 0.246 & 0.407 * & 0.629 & 1 & & & & \\
\hline $\mathrm{TiO} 2$ & 0.741 ** & $0.728 * *$ & $0.810^{* *}$ & $-0.847^{* * *}$ & $0.711^{* *}$ & $0.915^{* *}$ & -0.501 ** & -0.280 ** & $-0.303^{* *}$ & $-0.816^{* *}$ & -0.732 ** & 1 & & & \\
\hline $\mathrm{P} 2 \mathrm{O} 5$ & -0.277 & -0.273 & -0.304 & 0.292 & -0.365 & -0.171 & -0.274 & 0.650 ** & $0.837^{* *}$ & 0.040 ** & $0.291 * *$ & -0.100 ** & 1 & & \\
\hline $\mathrm{FeO}$ & 0.067 & $0.067^{* *}$ & $0.067^{* *}$ & 0.065 & $-0.410^{* *}$ & $0.180^{* *}$ & $0.184 * *$ & -0.010 ** & -0.223 & $-0.394 * *$ & $-0.320 * *$ & $0.409^{* *}$ & -0.127 ** & 1 & \\
\hline $\mathrm{Zr}$ & 0.860 ** & $0.852 * *$ & 0.889 ** & -0.937 & 0.861 ** & $0.971^{* *}$ & $-0.434 * *$ & $-0.225 * *$ & $-0.295^{* *}$ & -0.768 & $0-.665$ ** & $0.929 * *$ & $-0.198 * *$ & $0.329 *$ & 1 \\
\hline
\end{tabular}

Note: The correlation analysis was based on 76 samples; ${ }^{*}$ significant correlation at 0.05 level; ${ }^{* *}$ significant correlation at 0.01 level. 
Rare earth minerals are generally thought to mainly exist in three forms: in mineral lattice in the form of ionic compounds, such as monazite, fluorocarbon, REE-phosphates, and REE-carbonates; dispersed in impure minerals in the form of isomorphs, such as apatite and fluorite; and adsorbed on the surface of some minerals in an ionic state, such as clay minerals and mica minerals [33].

The main clay minerals in the red soil of Northern Vietnam include illite, kaolinite, chlorite, vermiculite, montmorillonite, plagioclase, potassium feldspar and goethite (discussed separately). According to the analysis of the correlation between REEs and major elements, REEs are adsorbed in clay minerals in an ionic state at the end of weathering. REEs are thought to be mainly adsorbed in kaolinite, chlorite, montmorillonite, and goethite. REEs have a strong correlation with $\mathrm{TiO}_{2}$ and $\mathrm{Zr}$, indicating that REEs may occur in minerals containing $\mathrm{Ti}$ and $\mathrm{Zr}$ in the form of cerium niobium perovskite, titanium-uranium, ilmenite, zircon, rutile, spinel, etc.

\subsubsection{Effects of Organic Matter and $\mathrm{pH}$ on REE Enrichment}

The TC and TOC contents in both profiles were low (Table 2). The average TC and TOC value in both profiles was less than 1\%. In the topsoil, the TC and TOC were significantly high, related to the vegetation and abundant sources of organic carbon on the surface. The high values of TC and TOC at the RSI may due to the gathering of water and nutrient elements here, creating a suitable environment for microorganism growth. However, it was not observed potentially.

The correlation between organic carbon and REEs is generally insignificant. However, with the increase in atomic radius, the hydrating ion radii of REEs increase gradually, and the coordination ability with inorganic and organic acid ions strengthens, and the migration ability increases [47]. Complexes formed by HREE with some inorganic and organic complexes, such as bicarbonate, phosphate, and humic acids, are generally much more stable than the complexes formed by LREE [48].

The REE concentration coefficient in Figure 7 shows that the laterite profile on Vietnam carbonate rocks had strong REE enrichment ability, especially at the RSI, depicting a single peak curve for the SC profile. However, in the TG profile, two more weak peaks were observed at -90 and $-150 \mathrm{~cm}$ in addition to the RSI peak, depicting a multi-peak curve (except for Ce) (Figure 7). Sun et al. [32] reported that a narrow and mutated alkaline barrier formed during the formation of residual soils (early stage of weathering). This barrier can effectively facilitate REE adsorption by clay minerals to form an enrichment peak. The $\mathrm{pH}$ of these two profiles showed weak acidity, significantly lower than that of the crust over carbonate rocks in subtropical areas in Southern China, where the average $\mathrm{pH}$ is 6.2 [32]. The maximum $\mathrm{pH}$ values in these two profiles appeared at the RSI, but with two more peaks at -60 and $-90 \mathrm{~cm}$ in TG profile, which correspond to the peak accumulation of REE
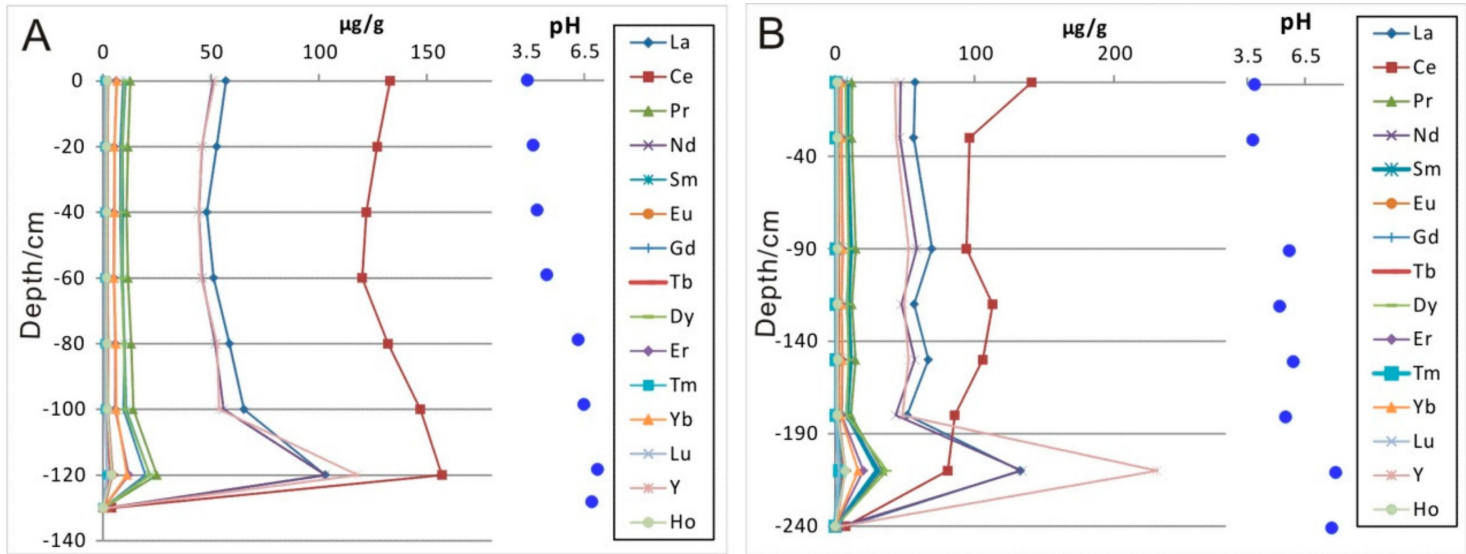

Figure 7. The variation of REEs and $\mathrm{pH}$ with depth in (A) SC and (B) TG profiles. 
Studies have shown that rare earth elements (except $\mathrm{Ce}$ ) are significantly correlated with $\mathrm{pH}$, and the correlation coefficient decreases with increasing atomic coefficient [49]. In this study, the correlation coefficients between $\mathrm{REE}$ from $\mathrm{La}$ to $\mathrm{Lu}$ and $\mathrm{pH}$ ranged from 0.656 to 0.639 . The correlation between LREE and $\mathrm{pH}$ was higher than HREE. On the one hand, the $\mathrm{pH}$ value directly affects the solubility of REE and changes their migration behavior. The $\mathrm{pH}$ value can also influence the activity of iron and manganese oxides. Within the $\mathrm{pH}$ range of the soil, the protons of hydroxyl groups on the surface of iron and manganese oxides are easily dissociated and are thus prone to obligate adsorption with REE [50].

\subsection{Differentiation Effect and Paleo-Environmental Evolution}

\subsubsection{Differentiation Effect}

The differentiation of LREE and HREE in both SC and TG profiles showed a LREE loss and HREE aggregation from topsoil to RSI, as shown in Table 2. The two reasons for the REE differentiation are: firstly, the leaching solution from upper layer was adsorbed and filtered by the clay layer, during which the LREE was absorbed; secondly, the stability of the complexes combined with the high concentration of $\mathrm{CO}_{3}{ }^{-}$can form relatively stable complex with REEs, and this stability increased with increasing elements ordinal number. Therefore, the HREE removed with weathering fluid was deposited at the RSI, resulting in enrichment of HREE [51].

More LREEs were lost much more in the SC profile than in the TG profile. The SC location has a stable tropical monsoon climate that is high in temperature and precipitation due to the influence of the southeast and southwest monsoons from the Pacific and Indian Oceans. Although the differentiation of REEs was small, the content of REE contents in weathering crusts were different (Table 2).

\subsubsection{Differentiation Between $\delta \mathrm{Ce}$ and $\delta \mathrm{Eu}$ and Significance of Paleo-Environment}

Besides LREE and HREE, the geochemical parameters $\delta C$ and $\delta$ Eu showed obvious differentiation (Figure 3). Generally, Ce consists of $\mathrm{Ce}^{3+}$ and $\mathrm{Ce}^{4+}$ under oxidizing conditions. The latter is prone to hydrolysis and precipitates after adsorption by Fe and Mn oxides, then separates from the other REEs. This effect leads to a deficit of Ce. A $\delta$ Ce value of 0.78 is generally adopted as the reference value to denote a redox environment [52]. Eu has two valence states: $\mathrm{Eu}^{2+}$ and $\mathrm{Eu}^{3+}$. The former can be oxidized to become the latter under alkaline oxidizing conditions. The reverse process can occur under strongly acidic and reducing conditions. Positive and negative anomalies occur when $\delta \mathrm{Eu}>$ 1 and $\delta \mathrm{Eu}<1$, respectively [53].

The weathering profile of SC profile basically showed the stable positive abnormal process of Ce, indicating that the external REDOX environment remained stable during the weathering process since the profile was formed. The differentiation process of the TG profile was complicated. First, significant positive anomalies exist in the top of the profile, which may be related to the strong oxidation of surface tillage soil under tilling. Some studies suggested that abundant organic matter (humic acid) on the surface may also contribute to the formation of positive Ce anomalies on the surface, as the complexation of humic acid with Ce is significantly stronger than that of other REEs [54]. According to the fluctuation process of Ce in the TG profile and its negative anomaly, the weathered TG limestone profile experienced several relatively reductive climatic environments.

Ce in the SC and TG profiles showed a positive anomaly at the upper layer, but a negative anomaly in the lower layer. In the oxidation environment, Ce was oxidized into $\mathrm{Ce}^{4+}$, and then hydrolyzed and formed undissolved hydroxide. The weak acid condition accelerated the process because $\mathrm{H}^{+}$has a catalytic effect on $\mathrm{Ce}^{4+}$ aggregation [55]. Therefore, the Ce in upper profile has a positive anomaly and less Ce leached downward. The RSI has an extremely negative anomaly interface for Ce.

Zhang et al. [56] found that the layer of the RSI was the location with a reductive environment that experienced long-term groundwater erosion, which is why the Ce has a positive anomaly in the upper section and a negative Ce anomaly in the lower section. The fluctuation of Ce in the TG weathering profile indicates the abrupt transition of the REDOX environment in the TG profile. 


\subsubsection{Environmental Significance of $Y$ and Ho}

$\mathrm{Y}$ and Ho have the same trivalent ionic radii, so they show the same geochemical behavior [57]. Under the processes of weathering, river transport, and marine deposit, $\mathrm{Y}$ and Ho would be significantly fractionated. The complex ability of Ho to coordinate with organic material or $\mathrm{HCO}_{3}{ }^{-}$is greater than that of $Y$, and $Y$ shows a stronger tendency to adsorb on solid particles in water-rock interactions [28].

The ratios of Y/Ho in the SC and TG profiles both increased with depth (Figure 8). However, the ratio of $\mathrm{Y} / \mathrm{Ho}$ was significantly different from that of the bedrock. For example, the $\mathrm{Y} / \mathrm{Ho}$ ratio in SC was higher than in bedrock, indicating that Ho leached in the SC laterite, whereas this ratio in the TG profile was lower than in the bedrock, indicating $\mathrm{Y}$ leached significantly. The high concentrations of organic matter and high $\mathrm{HCO}_{3}{ }^{-}$in the SC caused the Ho to complex together with organic matter and $\mathrm{HCO}_{3}{ }^{-}$. The climate of the SC profile was hot and rainy, and the water-rock interactions were much stronger than those of the TG profile, which further exacerbated the ratio of $\mathrm{Y} / \mathrm{Ho}$. Compared with the SC profile, the Y-leaching effect in TG was significantly greater due to the dry and hot weather around SC.

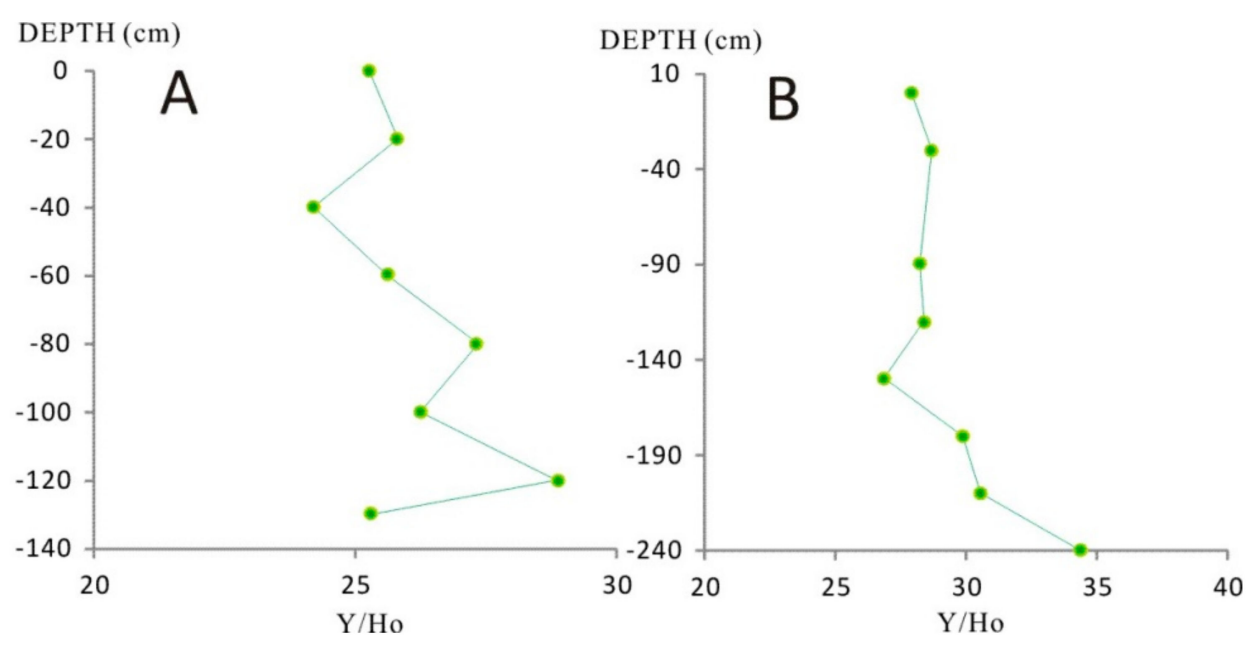

Figure 8. Variation of $\mathrm{Y} / \mathrm{Ho}$ ratio with the depth in the (A) SC and (B) TG profiles. The soil layers were the same as described in Figure 7 and Table 1.

\section{Conclusions}

Two typical weathering profiles developed on dolomite and limestone were the object of this study and our conclusions are summarized as follows:

Both SC and TG normalized weathering profiles patterns demonstrate an inheritance relationship with the bedrock. This suggests that the upper soil materials formed from the underlying carbonate rocks. The loss of distribution patterns in the upper profile and deposited at the RSI was the same as Chinese southeast subtropical carbonate rock weathering profiles. However, the enrichment factors of SC and TG profile were higher than in China. The laterization in SC was somewhat higher than in the TG profile due to the stable and high temperature oxidation environment in the SC profile. The variation of REE concentration with depth showed a single peak curve in SC, but a multi-peak curve (except for $\mathrm{Ce}$ ) in the TG profile. The different distribution patterns of $\mathrm{SC}$ and TG profiles were closely related with the climate environment: the SC profile had a high temperature and rainy climate, whereas the climate for the TG profile was high temperature and dry climate. The fractionation of $\Sigma$ HREE/ $\Sigma$ LREE, $\mathrm{Y} / \mathrm{Ho}$, and the differentiation in $\delta \mathrm{Ce}$ also suggested that the SC profile had a stable redox environment since the weathering process formation, whereas the TG profile experienced several relatively reducing climatic environments.

Author Contributions: All authors have read and agreed to the published version of the manuscript. Conceptualization, J.H. and W.S.; methodology, J.H. and Z.L.; software, W.X. and L.G.; validation, J.H.; formal 
analysis, L.X.; investigation, Z.L., J.H., L.X., L.G., W.X., N.D., N.Q.; data curation, Z.L.; writing一original draft preparation, Z.L.; supervision, J.H.; funding acquisition, J.H. and W.S.

Funding: This project was supported by the National Basic Research Program (2013CB956700) and Natural Science Foundation of China (41473122).

Acknowledgments: We would like to express our gratitude for the invaluable assistance from Tran Minh Thuan from the Vietnam Institute of Geosciences and Mineral Resources during the fieldwork of our study.

Conflicts of Interest: The authors declare no conflict of interest.

\section{References}

1. Zhang, Z.; Chen, X.; Soulsby, C. Catchment-scale conceptual modelling of water and solute transport in the dual flow system of the karst critical zone. Hydrol. Process. 2017, 31, 3421-3436. [CrossRef]

2. Wang, S.; Ji, H.; Ouyang, Z.; Zhou, D.; Zhen, L.; Li, T. Preliminary study on weathering and pedogenesis of carbonate rock. Sci. China Ser. D 1999, 42, 572-581. [CrossRef]

3. Yuan, D. Modern karstology and global change study. Earth Sci. Front. 1997, 4, 17-25.

4. Cao, J.; Yuan, D. Karst Ecosystem of Southwest China Constrained by Geological Setting; Geological Publishing House: Beijing, China, 2005.

5. Yuan, D.; Cai, G. The Science of Karst Environment; Chongqing Publishing Group: Chongqing, China, 1988.

6. Yuan, D. Karst in China; Geological Publishing House: Beijing, China, 1994.

7. Yang, H.; Zhang, L.; Yu, S.; Cao, J. Effects of different land-uses on the features of water-stable aggregates in karst and clasolite areas in Maocun, Guilin. Carsolog. Sin. 2012, 31, 265-271.

8. Zhu, Z.; Wang, J.; Huang, B.; Yu, S.H.; Xiang, M.; Zhang, G.M.; Liang, J.P.; Jiang, W.H.; Liang, C.S.; Wang, Q.G. Red soil, loess and global change. Quat. Sci. 1995, 3, 268-277.

9. Zhu, Z.; Xu, Y.; Wen, Q.; Pu, Z.; Zhou, H.; Wen, G.; Dai, T.; Liang, J.; Liang, C.; Luo, S. The stratigraphy and chronology of multicycle quaternary volcanic rock-red soil sequence in Leizhou Peninsula, South China. Quat. Sci. 2001, 21, 270-276.

10. Cui, Z.; Gao, Q.; Liu, G.; Pan, B.; Chen, H. The initial elevation of palaeokarst and planation surfaces on Tibet Plateau. Chin. Sci. Bull. 1997, 42, 934-939. [CrossRef]

11. Cui, Z.; Li, D.; Liu, G.; Feng, J.; Zhang, W. Characteristics and planation surface formation environment of the red weathering crust in Hunan, Guangxi, Yunnan, Guizhou and Tibet. Sci. China Ser. D 2001, 44, 162-175. [CrossRef]

12. Feng, J.L. Behaviour of rare earth elements and yttrium in ferromanganese concretions, gibbsite spots, and the surrounding terra rossa over dolomite during chemical weathering. Chem. Geol. 2010, 271, 112-132. [CrossRef]

13. Ji, H.; Wang, S.; Ouyang, Z.; Zhang, S.; Sun, C.; Liu, X.; Zhou, D. Geochemistry of red residua underlying dolomites in karst terrains of Yunnan-Guizhou Plateau-I. The formation of the Pingba profile. Chem. Geol. 2004, 203, 1-27. [CrossRef]

14. Wang, S.; Ji, H.; Sun, C. Preliminary study on REE distribution charactersitics in dolomitite weathering prifile in Pingba County, Guizhou. Chin. J. Geol. 2001, 36, 474-480.

15. Durn, G.; Ottner, F.; Slovenec, D. Mineralogical and geochemical indicators of the polygenetic natura of terra rossa in Istria, Croatia. Geoderma 1999, 91, 125-150. [CrossRef]

16. Miko, S.; Durn, G.; Prohić, E. Evaluation of terra rossa geochemical baselines from Croatian karst regions. J. Geochem. Explor. 1999, 66, 173-182. [CrossRef]

17. Mongelli, G.; Acquafredda, P. Ferruginous concretions in a Late Cretaceous karst bauxite: Composition and conditions of formation. Chem. Geol. 1999, 158, 315-320. [CrossRef]

18. Muhs, D.R.; Budahn, J.R. Geochemical evidence for African dust and volcanic ash inputs to terra rossa soils on carbonate reef terraces, northern Jamaica, West Indies. Quat. Int. 2009, 196, 13-35. [CrossRef]

19. Tu, G. Low Temperature Geochemisty; Science Press: Beijing, China, 1998.

20. Liu, Y. On the origin of the upper sinian cherts of Southern Anhui. J. Stratigr. 1998, 22, 154-161.

21. Yang, X.; Zhu, M.; Zhao, Y.; Zhang, J.; Guo, Q.; Pi, D. REE geochemical characteristics of the ediacaran-lower cambrian black rock series in Eastern Guizhou. Geol. Rev. 2008, 54, 3-15.

22. Taylor, S.R.; Mclennan, S.M. The Continental Crust: Its Composition and Evolution; Blackwell Scientific Publications: Palo Alto, CA, USA, 1985. 
23. Laveuf, C.; Cornu, S. A review on the potentiality of Rare Earth Elements to trace pedogenetic processes. Geoderma 2009, 154, 1-12. [CrossRef]

24. Fu, W.; Huang, X.; Yang, M.; Lei, L.; Niu, H.; Zhang, Y. REE geochemistry in the laterite crusts derived from ultramafic rocks: Comparative study of two laterite profiles under different climate condition. Earth Sci. J. China Univ. Geosci. 2014, 39, 716-732.

25. Hieu, P.T.; Chen, F.; Zhu, X.; Wang, F. Zircon Ages of Paragneisses from the Sinh Quyen Formation in Northwestern Vietnam and Their Geological Significances. Earth Sci. J. China Univ. Geosci. 2010, 35, 201-210.

26. He, S.; Yuan, D.; Tuyet, D. Characteristics of karst in northern vietnam and its relevant environmental problems. Carsolog. Sin. 1999, 18, 89-94.

27. Ji, H.; Ouyang, Z.; Wang, S.; Zhou, D. Element geochemistry of weathering profile of dolomitite and its implications for the average chemical composition of the upper-continental crust. Sci. China Ser. D 2000, 43, 23-35. [CrossRef]

28. Ji, H.; Wang, S.; Ouyang, Z.; Zhang, S.; Sun, C.; Liu, X.; Zhou, D. Geochemistry of red residua underlying dolomites in karst terrains of Yunnan-Guizhou Plateau II. The mobility of rare earth elements during weathering. Chem. Geol. 2004, 203, 29-50. [CrossRef]

29. Boynton, W.V. Cosmochemistry of the rare earth elements: Meteoric studies. In Rare Earth Element Geochemistry; Elsevier: Amsterdam, The Netherlands, 1984; pp. 63-114.

30. Nesbitt, H.W. Mobility and fractionation of rare earth elements during weathering of a granodiorite. Nature 1979, 279, 206-210. [CrossRef]

31. Lan, R.D. Redistribution and fractionation of rare-earth and other elements in a weathering profile. Chem. Geol. 1980, 30, 363-381.

32. Sun, C.; Wang, S.; Ji, H. Formation mechanism of the superhigh concentration of REE and the strong nagative Ce anomalies in the carbonate rock weathering profiles in Guizhou Province, China. Geochimica 2002, 31, 119-128.

33. Yang, Y.; Liu, C.; Yuan, K.; He, Z. Laterite formation process in southern China and its rare earth element (REE) geochemistry. Quat. Sci. 2000, 20, 469-480.

34. Chen, Z.; Gao, A.; Liu, Y.; Sun, H.; Shi, X.; Yang, Z. REE geochemistry of surface sediments in the Chukchi Sea. Sci. China Ser. D 2003, 46, 603-611. [CrossRef]

35. Taylor, S. Abundance of chemical elements in the continental crust: A new table. Geochim. Cosmochim. Acta 1964, 28, 1273-1285. [CrossRef]

36. Li, T.; Ni, S. Element abundances of the continental lithosphere in China. Geol. Prospect. 1997, 33, 31-37.

37. Braun, J.J.; Pagel, M.; Muller, J.P.; Bilong, P.; Michard, A.; Guillet, B. Cerium anomalies in lateritic profiles. Geochim. Cosmochim. Acta 1990, 54, 781-795. [CrossRef]

38. Braun, J.J.; Pagel, M.; Herbilln, A.; Rosin, C. Mobilization and redistribution of REEs and thorium in a syenitic lateritic profile: A mass balance study. Geochim. Cosmochim. Acta 1993, 57, 4419-4434. [CrossRef]

39. Koppi, A.J.; Field, D.J.; Geering, H.R.; Klessa, D.A.; Djh, C.; Edis, R. Rare earth element trends and cerium-uranium-manganese associations in weathered rock from Koongarra, Northern Territory, Australia. Geochim. Cosmochim. Acta 1996, 60, 1695-1707. [CrossRef]

40. Nesbitt, H.W.; Markovics, G. Weathering of granodioritic crust, long-term storage of elements in weathering profiles, and petrogenesis of siliciclastic sediments. Geochim. Cosmochim. Acta 1997, 61, 1653-1670. [CrossRef]

41. Bao, Z.; Zhao, Z. Geochemistry of mineralization with exchangeable REY in the weathering crusts of granitic rocks in South China. Ore Geol. Rev. 2008, 33, 519-535. [CrossRef]

42. Lottermoser, B.G. Rare-earth element mineralisation within the Mt. Weld carbonatite laterite, Western Australia. Lithos 1990, 24, 151-167. [CrossRef]

43. Murakami, H.; Ishihara, S. REE Mineralization of Weathered Crust and Clay Sediment on Granitic Rocks in the Sanyo Belt, SW Japan and the Southern Jiangxi Province, China. Resour. Geol. 2008, 58, 373-401. [CrossRef]

44. Sanematsu, K.; Takeru, M.; Sotouky, L.; Watanabe, Y. Mobility of Rare Earth Elements in Basalt-Derived Laterite at the Bolaven Plateau, Southern Laos. Resour. Geol. 2011, 61, 140-158. [CrossRef]

45. Li, J.; Liang, F.; Zhu, L.; Zuo, S. Physical and chemical properties of two typical weathered profiles of carbonate rocks. Carsolog. Sin. 2005, 24, 28-34.

46. Sun, C.; Wang, S.; Liu, X.; Ji, H. Review on the dating of the weathering profiles. Bull. Miner. Pet. Geochem. 2000, 19, 54-59. 
47. Singh, P.; Rajamani, V. REE geochemistry of recent clastic sediments from the Kaveri floodplains, southern India: Implication to source area weathering and sedimentary processes. Geochim. Cosmochim. Acta 2001, 65, 3093-3108. [CrossRef]

48. Byrne, R.H.; Kump, L.R.; Cantrell, K.J. The influence of temperature and pH on trace metal speciation in seawater. Mar. Chem. 1988, 25, 163-181. [CrossRef]

49. Ling, S.; Wu, X.; Yong, R.; Sun, C.; Xin, L.; Li, X.; Zhu, B. Geochemistry of trace and rare earth elements during weathering of black shale profiles in Northeast Chongqing, Southwestern China: Their mobilization, redistribution, and fractionation. Chem. Erde Geochem. 2015, 75, 403-417. [CrossRef]

50. Inguaggiato, C.; Censi, P.; Zuddas, P.; Londoño-Bonilla, J.M.; Chacón, Z.; Alzate, D.; Brusca, L.; D'Alessandro, W. Geochemistry of REE, $\mathrm{Zr}$ and $\mathrm{HF}$ in a wide range of $\mathrm{pH}$ and water composition: The Nevado del Ruiz volcano hydrothermal system (Colombia). Chem. Geol. 2015, 417, 125-133. [CrossRef]

51. Johannesson, K.H.; Stetzenbach, K.J.; Hodge, V.F.; Lyons, W.B. Rare earth element complexation behavior in circumneutral $\mathrm{pH}$ groundwaters: Assessing the role of carbonate and phosphate ions. Earth Planet. Sci. Lett. 1996, 139, 305-319. [CrossRef]

52. Wright, J.; Schrader, H.; Holser, W.T. Paleoredox variations in ancient oceans recorded by rare earth elements in fossil apatite. Geochim. Cosmochim. Acta 1987, 51, 631-644. [CrossRef]

53. Wang, X.; Tan, P. Distribution of tourism landscape resources in Yangtze River basin. Carsolog. Sin. 1986, 5, 311-317.

54. Chen, Z.; Yu, S.; Fu, Q.; Chen, B.; Zhang, L. Study on the organic metallogenic mechanism of weathering crust REE deposits. J. Chin. Rare Earth Soc. 1997, 15, 244-251.

55. Laufer, F. The Adsorption of Quadrivalent Cerium by Kaolinite. Clay Miner. 1984, 19, 137-149. [CrossRef]

56. Zhang, L.; Ji, H.; Gao, J.; Li, R.; Li, J. Geochemical characteristics of major, trace and rare earth elements in typical carbonate weathered profiles of Guizhou Plateau. Geochimica 2015, 44, 323-336.

57. Jahn, B.M.; Wu, F.; Capdevila, R.; Martineau, F.; Zhao, Z.; Wang, Y. Highly evolved juvenile granites with tetrad REE patterns: The Woduhe and Baerzhe granites from the Great Xing'an Mountains in NE China. Lithos 2001, 59, 171-198. [CrossRef] 